\title{
Researches Regarding the Existence of Phenotypic Correlations between Different Body Measurements in Females from Romanian Mioritic Shepherd Dog
}

\author{
Dorel DRONCA*1), Nicolae PACALA ${ }^{1)}$, Ioan BENCSIK ${ }^{1)}$, Teofil OROIAN ${ }^{2)}$, \\ Vasile $\mathrm{CIGHI}^{2)}$, Rasvan $\mathrm{POPA}^{3)}$, Ada CEAN ${ }^{1)}$, Adela MARCU ${ }^{1)}$, Alexandru DRONCA ${ }^{4)}$ \\ ${ }^{1)}$ Banat University of Agricultural Sciences and Veterinary Medicine "King Michael I of Romania" \\ from Timisoara, 119 Aradului Alley, Romania \\ ${ }^{2)}$ Faculty of Animal Sciences and Biotechnologies, University of Agricultural Sciences and Veterinary \\ Medicine Cluj-Napoca, 3-5 Manastur Street, 400372 Cluj-Napoca, Romania \\ 3) Faculty of Animal Sciences Bucharest, 59 Marasti Blv., Romania \\ ${ }^{4)}$ West University of Timisoara, Plautius-Andronescu Steet, Romania \\ *Corresponding author, email: ddronca@animalsci-tm.ro
}

Bulletin UASVM Animal Science and Biotechnologies 72(1) / 2015

Print ISSN 1843-5262; Electronic ISSN 1843-536X

DOI:10.15835/buasvmcn-asb:10417

\begin{abstract}
Romanian Mioritic Shepherd dog was selected from a natural population breed in Carpathian Mountains. The aim of this paper was to estimate the correlation coefficients between 6 characteristics, based on individual values from 23 females from Romanian Mioritic Shepherd dog breed. The animals were registered in the Romanian Mioritic Association Club from Romania. Following the analysis of the obtained phenotypic correlation coefficients, we concluded that between the height at withers and length of the body; height at withers and length of the head; length of the head and length of the skull, the correlations are strongly positive and between the other characters taken into study the correlations are average and weakly positive or weakly negative.
\end{abstract}

Keywords: body measurements, phenotypic correlation, Romanian Mioritic Shepherd dog

\section{INTRODUCTION}

For the animal genetic improvement knowing the correlations between features have a special importance. These have to predict before starting the selection what will be the development of the entire organism, if one or more features, that are the objective of the selection, will be modified during the generations.

Romanian Mioritic Shepherd dog is an excellent shepherd, watch and company dog, in which breeding is important to remember the factors that contribute to its success (Bura and Dronca, 2013). For the animal genetic improvement knowing the correlations between characters have special importance (Dronca, 2007).

\section{AIMS AND OBJECTIVES}

The research aims to estimate the phenotypic correlation coefficients among 6 characters, on an effective of 23 females from Romanian Mioritic Shepherd dog registered in Romanian Mioritic Association Club. The objective of the present paper was to establish the direction and intensity of the correlations between the 6 characters taken into study.

\section{MATERIALS AND METHODS}

Romanian Mioritic Shepherd dog was selected by from a natural population breed in Carpathian Mountains, reason why they are resistant and also rustic for feeding and maintenance. The food can 
comprise, both different and vegetal components and it can be administered as mush or granules (Bura and Dronca, 2013).

Romanian Mioritic Shepherd dog has the ability to adapt at different breeding conditions, which are easily accepted. It feels better when it is maintained in the yard, where it has enough room to move, play and rest.

In 23 females aged between 3 and 6 years, from Romanian Mioritic Shepherd dog from Romanian Mioritic Association Club, body measurements were performed for the 6 characters taken into study, as follows: the high at withers, body length, head length, skull length, skull width, and snout length. The resulted values were statistically analyzed. For the correlations' estimation the Pearson (r) correlation coefficient was calculated and for testing the correlation significance Student test was applied.

\section{RESULTS AND DISCUSSION}

The obtained results demonstrate that in 23 females aged between 3 and 6 years old, from Romanian Mioritic Shepherd dog, the high at withers is positively correlated with the length of the body $(\mathrm{r}=0.571 ; \mathrm{p}<0.01)$ and the length of the head $(\mathrm{r}=0.599 ; \mathrm{p}<0.01)$. Also, our measurements, shows a weak correlation of the high at withers with the length $(r=0.414)$ and width of the skull $(r=0.428)$ and the length of the snout $(r=0.325)$.

The length of the body is positively correlated with the width of the skull $(r=0.593 ; p<0.01)$, weakly correlated with the length of the head $(r=0.297)$, length of the skull ( $r=0.104)$ and length of the snout $(r=0.281)$.
The length of the head is strongly positively correlated with the length of the skull $(\mathrm{r}=0.865$; $\mathrm{p}<0.001$ ), also weakly positive with the width of the skull $(r=0.443 ; p<0.05)$ and the length of the snout $(r=0.223)$. The length of the skull is weakly negatively correlated with the length of the snout $(\mathrm{r}=-0.287)$ and positively with the width of the skull $(\mathrm{r}=0.191)$.

The obtained results demonstrates that between the 6 characters taken into study, the phonotypical correlations are of different intensities, strongly, average, weakly positive and weakly negative.

\section{CONCLUSION}

Following the analysis of the obtained phenotypic correlation coefficients, we concluded that between the height at withers and length of the body; height at withers and length of the head; length of the head and length of the skull, the correlations are strongly positive and between the other features taken into study the correlations are average positive, weakly positive or weakly negative.

We recommend for the dog owners from this breed, that in the female selection these correlations and their intensity, demonstrated in this paper, should be taken into consideration.

\section{REFERENCES}

1. Bura M and Dronca D (2013). Program for genetic improvement of the dogs effective of Romanian Mioritic Shepherd Dog breed from Romanian Mioritic Association Club. Ed. Mirton, 66-68.

2. Dronca D (2007). Genetic amelioration of animal population. Ed. Mirton, 154-158. 